\title{
SOIL FREEZING AND THAWING AS AFFECTED BY SOIL MOISTURE CONTENT AND AIR TEMPERATURE
}

\author{
Mikкo SillanPÄÄ \\ Department of Soil Science, Agricultural Research Centre, Helsinki
}

Received September 7, 1961

In cold climates the processes of freezing and thawing have been found to affect not only the physiology of wintering crops but also the physical properties of soils, such as hydraulic conductivity and aggregation. Some of the latest studies $(2,3,4)$ show that the effects of freezing and thawing on aggregation depends largely on the conditions under which these processes take place. Both soil moisture content and freezing temperature affect the phenomena of frost formation and thus aggregation. Large aggregates suffer great destruction when frozen at high moisture content $(2,3,4)$ but simultaneously there may be a build up taking place in the range of smaller sized aggregates which also is pronounced at high moisture contents (3). At lower moisture contents the freezing temperature has little effect on aggregation but at higher moisture contents a fast rate of freezing seems to cause more destruction of large aggregates and less building up of small ones $\left.{ }^{1}\right)$. This is apparently due to the size and number of the ice crystals formed, these features depending on both moisture content and on freezing temperature.

This study was conducted to obtain more information about the relationships between the factors, air temperature and soil moisture content, both of which affect the nature of the soil freezing and thawing phenomena and thus indirectly aggregation and other physical properties of soils.

\section{Materials and methods}

Surface samples of Guelph loam, $60 \mathrm{~g}$ in weight and $57.7 \mathrm{ml}$ in volume, were used to study the effects of soil moisture content and air temperature on the time required to freeze or thaw the soil sample. The samples were wetted in beakers with distilled water to moisture contents of 0.8 (air dry), 12.5, 25.0, 37.5 and 50.0 per cent by volume, and covered with plastic to avoid moisture losses during the treatments.

1) Unpublished data by the author. 
For comparison of the freezing and thawing phenomena in soils of different texture and organic matter content, surface samples $90 \mathrm{ml}$ in volume of three Grey Brown Podsolic soils, Fox sandy loam, Guelph loam and Haldimand clay loam were used (Table 1).

Table 1. Particle size distribution, organic matter content, and bulk density of the three soils under study.

\begin{tabular}{|c|c|c|c|c|c|c|c|c|c|c|c|c|}
\hline Soil type & $<0.002$ & $\begin{array}{r}0.002 \\
-0.005\end{array}$ & $\begin{array}{l}0.005 \\
-0.01\end{array}$ & $\begin{array}{r}0.01 \\
-0.02\end{array}$ & $\begin{array}{r}0.02 \\
-0.05\end{array}$ & $\begin{array}{r}0.05 \\
-0.10\end{array}$ & $\begin{array}{r}0.10 \\
-0.25\end{array}$ & $\begin{array}{r}0.25 \\
-0.50\end{array}$ & $\begin{aligned} 0.50 \\
-1.0\end{aligned}$ & $\begin{array}{l}>1.0 \\
\mathrm{~mm} .\end{array}$ & O.M. & $\mathrm{Db}$ \\
\hline & $\%$ & $\%$ & $\%$ & $\%$ & $\%$ & $\%$ & $\%$ & $\%$ & $\%$ & $\%$ & $\%$ & $\mathrm{~g} / \mathrm{cc}$. \\
\hline $\begin{array}{l}\text { Fox sandy } \\
\text { loam } \\
\text { Guelph }\end{array}$ & 12.3 & 1.1 & 5.3 & 10.7 & 23.0 & 14.6 & 18.8 & 8.9 & 4.6 & 0.7 & 2.4 & 1.15 \\
\hline $\begin{array}{l}\text { loam } \\
\text { Haldimand } \\
\text { clay loam }\end{array}$ & 16.6 & 5.9 & 7.1 & 10.4 & 28.8 & 10.3 & 13.8 & 4.2 & 2.1 & 0.8 & 3.4 & 1.04 \\
\hline
\end{tabular}

Thermocouples connected to a 12-point temperature recorder were placed in the centre of each sample. The samples were frozen and thawed in controlled $\left( \pm 0.5^{\circ} \mathrm{C}\right)$ adjustable freezers at various temperatures and the temperature changes with time were read from the recorder sheets.

\section{Results and discussion}

To give a general picture of the temperature-time curves an example is presented in Fig. 1. As shown by the curves, the moisture content of a soil is the factor dominating the freezing phenomena. The differences in cooling time from $24^{\circ} \mathrm{C}$

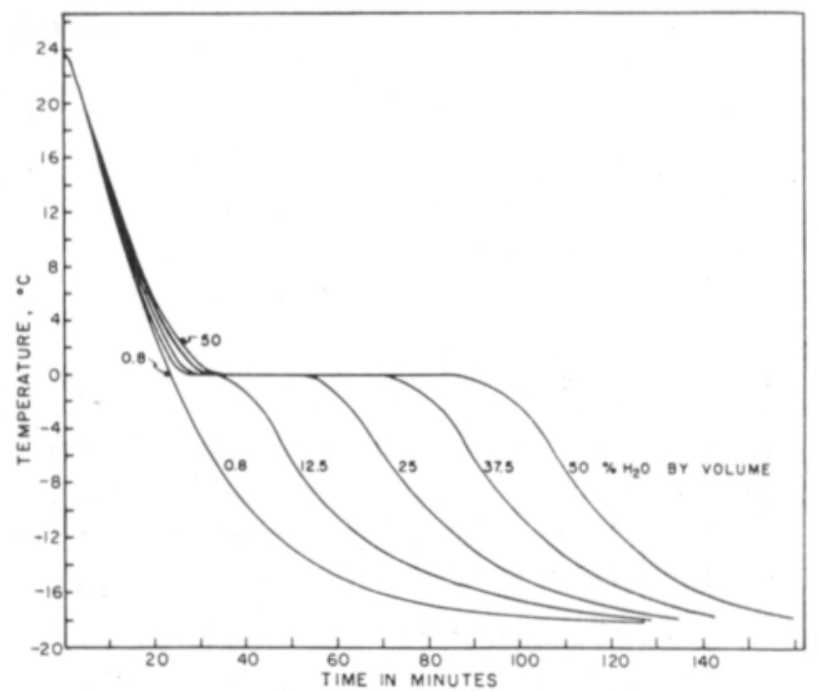

Fig. 1. Temperature-time curves for Guelph loam soil (60 gram samples) at five different moisture levels as frozen at $-18.9 \pm 0.5^{\circ} \mathrm{C}$. 
to freezing point between samples at different moisture levels are clear but rather small when compared with the differences in the $\mathrm{f} \mathrm{re} \mathrm{e} \mathrm{z}$ i n $\mathrm{g}$ t i m e (i.e. the time after the samples reach the temperature of $0^{\circ} \mathrm{C}$ and frost formation starts to the time the soil is frozen and the temperature falls below $0^{\circ} \mathrm{C}$ ). The thawing curves where the change of temperature is in the opposite direction were very similar in shape. In the following the factors affecting the speed of these processes are discussed.

The time taken for freezing or thawing the soil sample is a linear function of soil moisture content as indicated by the high correlation coefficients $(0.990-0.996)$ of the regressions in Table 2 . The data are given in Fig. 2 . It should be noted that these regressions are relative in nature and characterize only the freezing and thawing times for a certain size and shape of soil samples. The effect of the size of soil samples was not a part of this study.

Table 2. Regression equations of freezing times $\left(Y_{1}, \min \right)$ and thawing times $\left(Y_{2}\right.$, min) on the soil moisture content $(Z, \%$ by $V o l$.$) when the 60 \mathrm{~g}$ soil samples were frozen and thawed at various temperatures.

\begin{tabular}{cccc}
\hline $\begin{array}{c}\text { Freez. } \\
\text { temp. } \\
{ }^{\circ} \mathrm{C}\end{array}$ & Freezing & $\begin{array}{c}\text { Thaw. } \\
\text { temp. } \\
{ }^{\circ} \mathrm{C}\end{array}$ & Thawing \\
\hline-3.0 & $\mathrm{Y}_{1}=-30.5+9.226 \mathrm{Z}$ & +1.4 & $\mathrm{Y}_{2}=-55.3+20.566 \mathrm{Z}$ \\
-5.2 & $\mathrm{Y}_{1}=-10.9+4.995 \mathrm{Z}$ & +4.4 & $\mathrm{Y}_{2}=-14.2+5.605 \mathrm{Z}$ \\
-8.3 & $\mathrm{Y}_{1}=-6.3+3.146 \mathrm{Z}$ & +6.9 & $\mathrm{Y}_{2}=-7.2+3.527 \mathrm{Z}$ \\
-11.6 & $\mathrm{Y}_{1}=-3.7+2.132 \mathrm{Z}$ & +10.0 & $\mathrm{Y}_{2}=-6.6+2.288 \mathrm{Z}$ \\
-18.9 & $\mathrm{Y}_{1}=-2.8+1.168 \mathrm{Z}$ & +22.2 & $\mathrm{Y}_{2}=-2.9+1.006 \mathrm{Z}$ \\
-26.1 & $\mathrm{Y}_{1}=-3.6+0.925 \mathrm{Z}$ & & \\
\hline
\end{tabular}

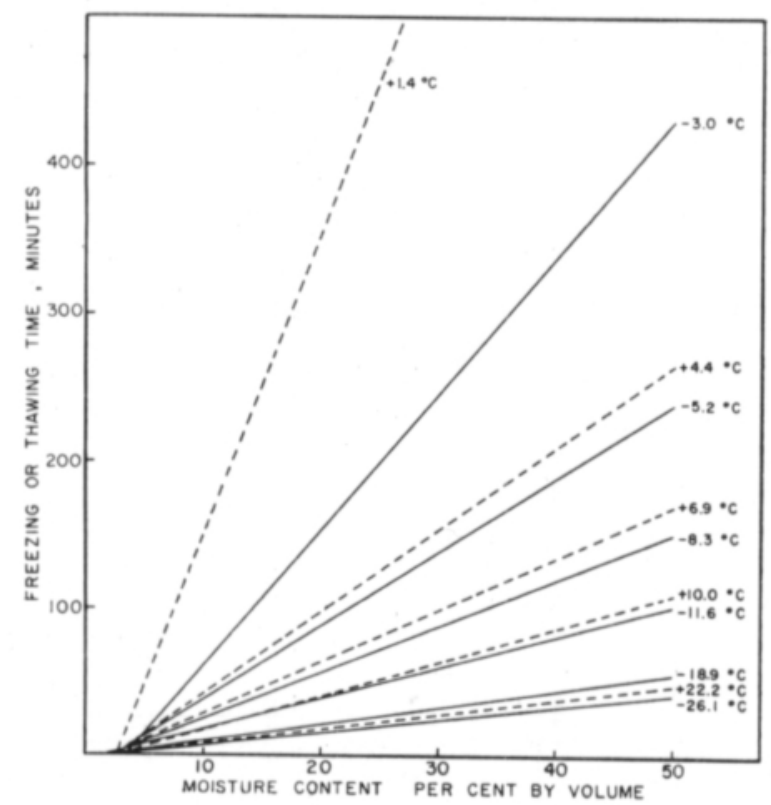

Fig. 2. Relations of freezing time (solid lines) and thawing time (dotted lines) at various temperatures to soil moisture content (60 gram samples). 
An interesting feature of the data in Fig. 2, is that all the lines cross the $\mathrm{X}$ axis between 2 and 4 per cent moisture. This means that soil moisture up to this level was not frozen at $0^{\circ} \mathrm{C}$. This is in agreement with the results of Kolesnikov (1), who points out that only water in the free state is transformed into ice during soil freezing. Combined water, the amount of which varies in different soils, freezes later with a significant decrease of soil temperature below the freezing point.

Table. 3. Regression equations of freezing time $\left(Y_{1}\right.$ min) and thawing time $\left(Y_{2}\right.$, min $)$ on the temperature of the surrounding air during the freezing and thawing processes $\left(T,{ }^{\circ} \mathrm{C}\right)$ at different soil moisture levels $(60$ gram soil samples).

Soil moisture

content

Freezing

Thawing

$\%$ by Vol.

$\begin{array}{lll}50 & \log \mathrm{Y}_{1}=3.14-1.0661 \log (-\mathrm{T}) & \log \mathrm{Y}_{2}=3.13-1.0794 \log \mathrm{T} \\ 37.5 & \log \mathrm{Y}_{1}=3.08-1.1110 \log (-\mathrm{T}) & \log \mathrm{Y}_{2}=3.04-1.1032 \log \mathrm{T} \\ 25 & \log \mathrm{Y}_{1}=2.83-1.0713 \log (-\mathrm{T}) & \log \mathrm{Y}_{2}=2.78-1.0751 \log \mathrm{T} \\ 12.5 & \log \mathrm{Y}_{1}=2.28-1.0332 \log (-\mathrm{T}) & \log \mathrm{Y}_{2}=2.36-1.1226 \log \mathrm{T}\end{array}$

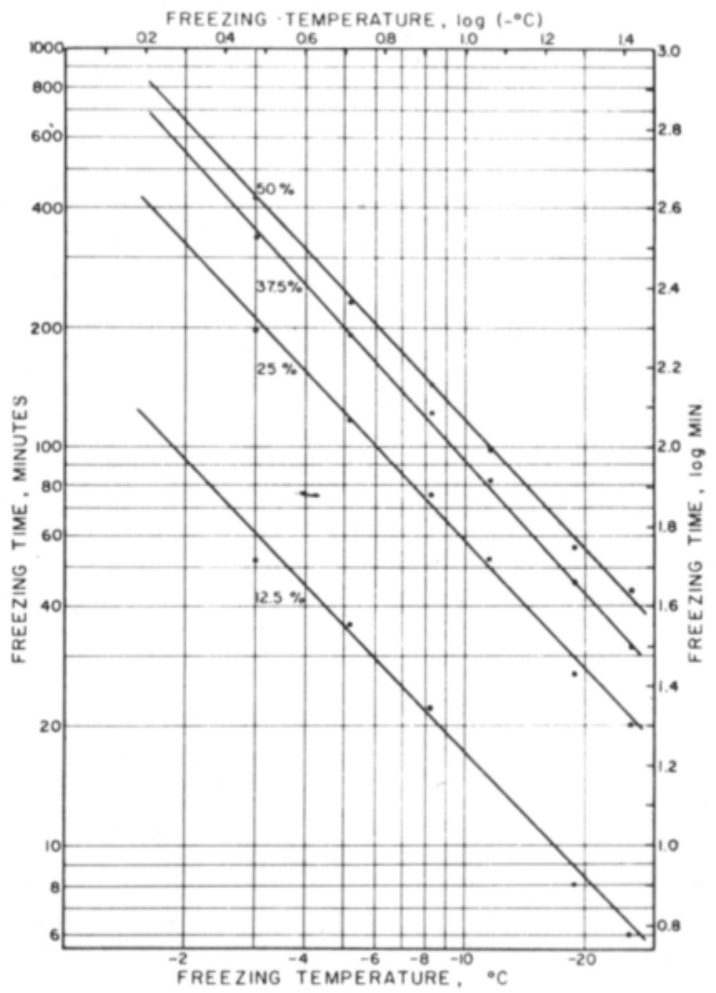

Fig. 3. Relation of freezing time to the temperature of surrounding air during freezing at four soil moisture levels (60 gram samples of Guelph loam). 
The effect of the surrounding a i r-temperat u re during freezing and thawing on the time taken by these processes was found to be a linear function when plotted on a log-log scale. For Guelph loam soil (60 gram samples) at four different moisture levels, the equations for the regressions are given in Table 3 and the data are plotted in Figures 3 and 4 . The high correlation coefficients $(>0.99)$ of these regressions show the good fit of the regressions. Furthermore, the similarity of the regressions of freezing and thawing indicates the reversibility of these processes differing only in the direction of the process.

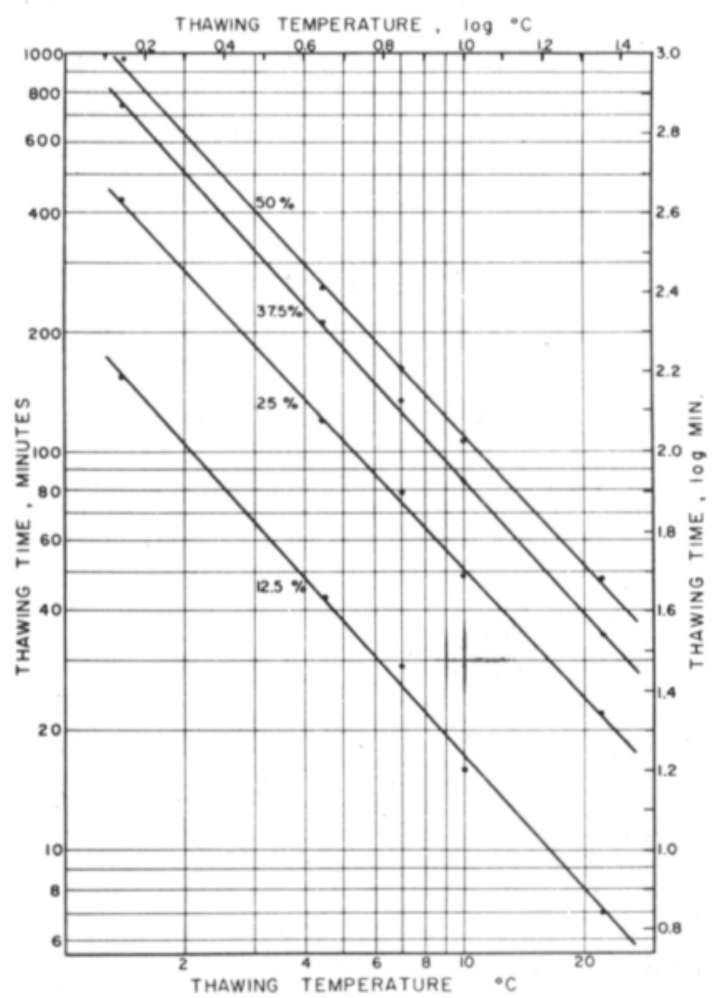

Fig. 4. Relation of thawing time to the temperature of surrounding air during thawing at four soil moisture levels (60 gram samples of Guelph loam).

Table 4. Regression equations of freezing time $(Y, \min )$ on the soil moisture content $\left(Z_{1}, \%\right.$ by Vol. and $Z_{2}, \%$ by $W t$. $)$ and on the soil + water weight $(X$, grams $)$ for regression lines in Fig. $5(r=$ correlation coefficient $)$.

\begin{tabular}{llll}
\multicolumn{1}{c}{ Soil type } & Freezing at $-8.2{ }^{\circ} \mathrm{C}$ & $\mathrm{r}$ \\
\hline Fox sandy & $\mathrm{Y}=-4.4+5.292 \mathrm{Z}_{1}$ & \\
loam & $\mathrm{Y}=-4.4+6.086 \mathrm{Z}_{2}$ & 0.96 \\
& $\mathrm{Y}=-614+5.889 \mathrm{X}$ & \\
\hline Guelph & $\mathrm{Y}=-8.8+4.975 \mathrm{Z}_{1}$ & \\
loam & $\mathrm{Y}=-8.8+5.174 \mathrm{Z}_{2}$ & 0.94 \\
& $\mathrm{Y}=-530+5.556 \mathrm{X}$ & \\
\hline $\begin{array}{l}\text { Haldimand } \\
\text { clay loam }\end{array}$ & $\mathrm{Y}=-27.2+4.958 \mathrm{Z}_{1}$ & \\
& $\mathrm{Y}=-27.2+4.710 \mathrm{Z}_{2}$ & 0.94 \\
\hline
\end{tabular}




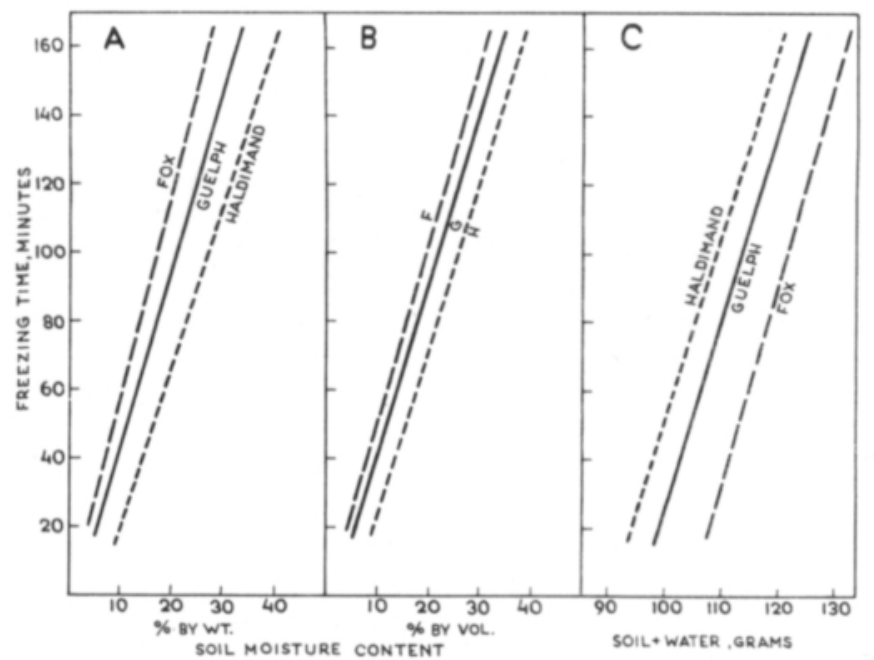

Fig. 5. Comparison of freezing times of three soils (90 ml samples). Regression of time is given on soil moisture content as percentage by weight and percentage by volume and on the weight of soil + water (grams).

The results of the freezing-thawing experiments, in which three mineral soils were compared, are represented by a typical example given in Table 4 and Fig. 5 . The differences in freezing times between the soils were smaller than the differences due to the soil moisture content. Furthermore, when soils of different bulk densities were compared, the freezing rates as affected by soil moisture content proved more uniform when the soil moisture content was expressed as percentage by volume rather than by weight (Fig. 5, A, B) in samples of equal volume. This and the distance between the lines in Fig. 5, C indicate that the actual amount of water to be frozen primarily determined the rate of the process. Thus in mineral soils the indirect effects of those soil factors that determine the moisture-holding properties of soils in field conditions are more pronounced than the direct effects of the soil properties on freezing and thawing rates. Accordingly, when the freezing-thawing properties of different soils are compared, soils at equivalent $\mathrm{pF}$ levels or other soil moisture indexes, such as wilting point, field capacity, moisture equivalent etc. are likely to give a better picture of the course of these processes in various soils in the field than soils at the same moisture percentages either by volume or by weight.

\section{$S u m m$ ary}

A laboratory study was conducted to evaluate the effects of soil moisture and air temperature on soil freezing and thawing. The time required to freeze or thaw a soil sample was a linear function of soil moisture content and a linear log-log function of the temperature of the surrounding air.

The differences in the freezing-thawing properties between the three mineral soils under study were small when compared with the effect of soil moisture content. 
In field conditions the indirect effects of those soil properties that determine the moisture-holding properties of various soils seem to be of prime importance in influencing the course of the freezing and thawing processes.

Acknowledgement. This study was made in the Department of Soils, Ontario Agricultural College, under a National Research Council of Canada Postdoctorate Fellowship. The author wishes to express his sincere thanks to the National Research Council and the Ontario Agricultural College for making this study possible.

\section{REFERENCES}

(1) Kolesnikov, A. G. 1952 [A modification of the mathematical formation of the problem of soil freezing]. Dokl. Akad. Nauk. 82: 889-891. (Ref.Soils Fert. XVI, p. 361).

(2) Logsdail, D. E. and WebBer, L. R. 1959. Effect of frost action on structure of Haldimand clay. Canadian J. Soil Sci. 39: 103-106.

(3) SillanpäÄ, M. 1961. The dynamic nature of soil aggregation as affected by cycles of freezing and thawing. Acta agric. scand. 11: $87-94$.

(4) Slater, C. S. and Hopp, H. 1949. The action of frost on the waterstability of soils. J. Agr. Res. 78: $341-364$.

SEL OST U S :

\section{MAAN KOSTEUDEN JA ILMAN LÄMPÖTILAN VAIKUTUS MAAN ROUTAANTUMISEEN JA SULAMISEEN}

Mikкo SillanpäÄ

\section{Maantutkimuslaitos, maatalouden tutkimuskeskus, Helsinki}

Maan routaantumisen tapahtuessa vallitsevilla olosuhteilla on todettu olevan merkitystä maan fysikaalisiin ominaisuuksiin, erityisesti sen rakenteeseen, koska jääkiteiden muodostumistapa, niiden koko ja lukumäärä riippuvat lähinnä jäätymisnopeudesta ja maan kosteusasteesta.

Tässä tutkimuksessa on tarkasteltu jäätymis- ja sulamisprosessien tapahtuessa vallitsevan lämpötilan ja maan kosteusasteen vaikutusta näiden prosessien nopeuteen. Lisäksi suoritettiin vertailevia kokeita kolmella kivennäismaalajilla (taulukko 1).

Tutkimuksessa mitattiin lämpötilan muutokset maanäytteiden keskipisteissä automaattisella, 12-pisteen mittauslaitteella. Kuvassa 1 on esitetty tyypillinen lämpötila-aika käyrästö viidessä eri kosteuspitoisuudessa oleville näytteille. Jäähtymisaikojen $\left(+\mathbf{2 4}^{\circ}- \pm 0^{\circ} \mathrm{C}\right)$ riippuvuus maan kosteudesta on selvä, mutta erojen suuruus on vähäinen verrattuna eri näytteiden jäätymisaikojen (käyrien vaakasuora osa $0^{\circ} \mathrm{C}$ :ssa) eroihin.

Jäätymis- ja sulamisaikojen todettiin kasvavan lineaarisesti maan kosteuspitoisuuden funktiona (taulukko 2 ja kuva 2). Suorat leikkaavat X-akselin $2-4$ prosentin kohdalla, mikä viittaa siihen, että tässä lämpötilassa on vain ns. vapaa vesi jäätynyt ja ns. sidottu vesi jäätyy vasta melkoisesti alapuolella $0^{\circ} \mathrm{C}$ olevassa lämpötilassa (1).

Jäätymisen tapahtuessa vallitsevan ilman lämpötilan laskiessa kasvaa jäätymisnopeus lineaarisesti logaritmi-logaritmi funktiona (taulukko 3 ja kuva 3). Sulamisnopeuden ja lämpötilan välinen riippuvuussuhde on samanlainen eroten vain prosessin suunnassa (taulukko 3 ja kuva 4).

Vertailtavina olleiden kolmen kivennäismaalajin väliset jäätymis- ja sulamisnopeuksien erot olivat pienemmät kuin kunkin maalajin kosteusasteen aiheuttamat erot (taulukko 4 ja kuva 5), joten kenttäolosuhteissa maan kosteutta säätelevien maaperätekijäin, kuten lajitekoostumuksen, orgaanisen aineksen ja rakenteen, välillinen vaikutus näiden prosessien nopeuteen lienee olennaisempi kuin niiden suoranainen vaikutus. 